corroded, their original diameter being reduced here and there to $\frac{1}{\mathrm{~s}}$ inch.

February $25^{\text {th }}$ was a rainy day during the forenoon, with heavy wind from the south-east, but in the afternoon the sky cleared. There had been no sign of thunder all day. At 5 P.M. my wife, my son, and myself were standing under the flagstaff and within Io feet of a mooring chain, watching the bay, when the vane was suddenly struck by lightning, which broke the mast short off in two places, tearing and splitting the wood between the vane and the iron guy ropes. Through these the discharge then passed to the ground, but three out of the four mooring chains were broken. Not only one, but many links in each of these chains were snapped, both above and below ground, and several of the links were broken in two places at once. The fractures were crystalline and showed no signs of heat. On the garden path, and within a yard of myself, stood an iron roller, towards which the discharge ploughed two shallow furrows in the gravel; one of these is 8 feet long and terminates in a splash of gravel upon the roller.

The broken mast and vane fell to the ground close to us. The former was blackened from end to end around half its circumfer. ence, and the edges of the discoloration form ragged splashes. The brass tube forming the vane was ripped open, and all solder about the vane melted. Below the point where the wire ropes were attached to it the mast was uninjured. Shivered fragments of the staff were found on the ground as far as $\mathrm{r} 5 \mathrm{O}$ feet to windward. Heavy bail followed the flash, the wind falling instantly to a dead calm; a second but distant flash was seen twenty minutes later, after which there was no more lightning. The discharge startled the whole village of Paignton; the coast guard officer compares the explosion to that of a 300 pounder gun; and at Torquay, $3 \frac{1}{2}$ miles distant, a scientific friend speaks of both flash and crash as most terrific.

I must now attempt to describe the effects on ourselves and the impressions on our senses, though I am conscious of difficulty in avoiding subjective matter here. Of the three, my wife only was "struck," and fell to the ground, my son and myself remaining erect, and all three retaining consciousness. For more than half an hour my wife lost the use of her lower limbs and left hand, both of which became rigid. From the feet to the knees she was splashed with rose-coloured tree-like marks, branching upwards, while a large tree-like mark, with six principal branches diverging from a common centre, thirteen inches in its largest diameter, and bright rose red, covered the body. None of us are certain of having seen the flash, and my wife is sure she saw nothing. As to the noise, my wife heard a "bellowing" sound and a "squish," recalling freworks : my son also heard a "bellow," while I seemed conscious of a sharp explosion. My wife describes her feeling as that of "dying away gently into ciarkness," and being roused by a tremendous blow on the body, where the chief mark was afterwards found. My son and myself were conscious of a sudden and terrific general disturbance, and he affrms that he received a severe and distinctly electrical shock in both legs. My left arm, shoulder, and throat especially suffered violent disturbance, but I did not think it was electrica]. As I turned to help my wife, who was on the ground, I shouted, as I thought, that I was unhurt, and hoped they were also, but it seems I only uttered inarticulate sounds, and my son, in lis first attempt to answer, did the same. This, however, was only momentary; in an instant we both spoke plainly.

Neither of us referred the occurrence immediately to its true cause, but the idea of being fired at was present to all our minds, my wife indeed remained of opinion that she was shot through the body, until she heard me speak of lightning. An infinitesimal lapse of time enabled my son and myself to recognise lightning; but I cannot say whether I did so before or after my first glimpse of the wreck on the ground. Neither of is heard or saw the mast fall, though it descended fifty feet, and fell on hard gravel close to us. My son and myself both experienced a momentary feeling of intense anger against some " person or persons unknown," further showing that we primarily referred the shock to some conscious agency. I ought perhaps to add, that neither of us felt any sensation of fear at the time; but we were all very nervous for several days after.

I have endeavoured to keep to fact throughout, but I venture to add a remark made by my wife as we raised her frum the ground: "I feel quite sure that death from lightning must he absolutely painless ;" and I offer it as an unconscious corroboration of views on this subject which our experience seems to strengthen.
Though no electrician, I conclude from the splash of gravel on the garden roller that the discharge was from cloud to earth, and the oxidised mooring-chains being inadequate to carry it all to ground, my wife formed a conductor for one of many sprays fying in all directions from the broken links.

Paignton, March Io

D. PIDGEON

\section{Mr. G. Darwin's Paper on Cousin Marriages}

THE report in the Times of my paper on Cousin Marriages, read before the Statistical Society on Tuesday, the 16 th inst., contains an important error. It is there made to appear that out of 8,170 lunatics and idiots in England and Wales, 4,308 were offspring of first cousins. This should have run :-Answers with respect to the parentage of 4,308 out of the 8 , I 7o patients were obtained; 142 to 149 of these were stated to be offspring of first cousins, that is to say, nearly $3 \frac{1}{2}$ per cent. Similarly, out of 564 patients in Scotland, $5^{1}$ per cent. were found to be offspring of first cousins.

I had hoped that the monstrous nature of the mistake would have shown it to be a misreport; but although the error was pointed out in the next day's Times, I have already had my attention drawn to it several times, and you would therefore be conferting a great favour on me by giving further publicity to the correction in your columns.

Down, March $2 I$

\section{Mounting Acari for the Microscope}

I HAVE much pleasure in detailing, for the benent of your correspondent Mr. R. C. Fisher, a method I practised extensively some years since, and with the best possible results, in preparing Acari for the cabinet. The section then occupying my attention was the group of the Hydrachnidce, or "Water Mites," and to illustrate which I possess some hundred slides representing twenty or thirty species in various conditions of development. In first attempting to preserve these as permanent objects for the microscope I encountered difficulties similar to those of Mr. Fisher; the little animals heing hard to kill, and their limbs in death doubling beneath to the great detriment of their personal appearance. As an experiment, I tried immersing them in boiling water, and was rewarded by finding this treatment to achieve everything that could be desired, death being instantaneous, and with the limbs rigidly extended in perfect symmetry. This method proved equally efficacious with various earth mites, such as Tromitidium. A watch-glass, spirit lamp, and camel's hair brush is all the apparatus necessary. The occupation of other and larger "fish to fry" has unfortunately prevented my prosecuting the study of this most interesting group of the Arachnida so far as I first proposed.

Manchester Aquarium

W. SAVILLE-KENT

\section{The "Wolf" in the Violoncello}

CAN any of your readers explain the reason of the unpleasant jarring noise which is sometimes found in certain notes of the violoncello, termed by musicians the wolf?

In an instrument in my possession the relolf exists on one note only, viz, the $F$ of the bass clef ( This is not due to a defect in the string, as the same note stopped on the $G$ string still produces the zeolf.

It seems, therefore, that from some defect in the instrument itself, it is unable to vibrate in conjunction with a string having a certain rate of vibration, though it will take up the vibrations of every other but this particular note. HERBERT F. FRYER

\section{Coloured Shadows}

Six Grove's cells were connected with one of Ladd's large induction coils, and the secondary current, confensed by two lirge Leyden jars, was sent, in the usual way, between two pairs of metallic electrodes, in order to examine their spark spectra.

Two of the electrodes were of platinum: these may be called pair A.

Of the other pair, B, one electrode was of platinum, and the other of the metal to be examined.

Ilace a piece of white paper equidistant from, and on one side of, the two sparks. Hold the finger so that a shadow of it may 